\title{
MEASUREMENT ON STAGES WITH 3D BLADINGS AND DIFFERENT RELATIVE WIDTH OF STATOR BLADES
}

\author{
Petr MILCAK, Michal HOZNEDL, Pavel ZITEK
}

\begin{abstract}
Two variants of a stage with modern 3D bladings were tested on a single-stage air turbine to determine the influence of relative width of stator blades (nozzles). The first case means a high-density nozzle row with $t / B_{a x}=0.61$; the second one represents a low-density row with $t / B_{a x}=1.12$. The $3 D$ shaping of both nozzle cases is based on the same design features. Rotor blades (buckets) are kept the same (also 3D shaped). Comparisons of overall stage efficiency as well as measured flow fields data are presented in the paper.
\end{abstract}

\section{INTRODUCTION}

Energy losses caused by the secondary flow features represent a significant part of the overall stage losses. Their portion becomes more important primarily in stages with relatively short blades. The 3D blade shaping is considered as an efficient tool for reduction and control of the secondary flow impacts [3]. The research on secondary flow and 3D blade shaping is one of the principal research topics done at the Department of Power System Engineering. This study means a part of the long-term collaboration with the SKODA POWER company.

The investigation in the previous years was focused on experimental testing of the influence of stator blades shape (see [4] and [5]), but all the tested cases had the same (prismatic) rotor blades. The modern approach of steam turbine stage design is based on advanced 3D shaping of nozzles together with suitable shaping of buckets. This paper presents experimental results of two variants of this "Full3D" stage.

The first tested stage variant has the relative width of nozzles $t / B_{a x}=0.61$ (firstly presented in [2] and in more details in [1]). The second variant has the same buckets, only nozzles were modified - changed blade number and relative width to $t / B_{a x}=1.12$. The principle of 3D shaping is the same for both tested cases. The designation Full3Dv1 resp. Full3Dv2 will be used to distinguish the cases.

This implies the current research is focused not only on the 3D blade shaping, but also on the influence of nozzles relative width. The present study is going to be extended in 2011 by the third nozzle case (Full3Dv3) with $t / B_{a x}=0.92$; so called middle-density row.

\footnotetext{
- Ing. Petr MILCAK, Ph.D., Department of Power System Engineering, University of West Bohemia, Univertizni 22, 30614 Pilsen, pmilcak@kke.zcu.cz

Ing. Pavel ZITEK, Department of Power System Engineering, University of West Bohemia, Univertizni 22, 30614 Pilsen, zitek@kke.zcu.cz

Ing. Michal HOZNEDL, Ph.D., experimental research, SKODA POWER, Tylova 1/57, 30128 Pilsen, michal.hoznedl@doosan.com
}

This is an Open Access article distributed under the terms of the Creative Commons Attribution License 2.0, which permits unrestricted use, distribution, and reproduction in any medium, provided the original work is properly cited. 


\section{EXPERIMENTAL TURBINE}

Both bladings cases were tested on a single-stage air turbine which is placed in the laboratory of the Department of Power System Engineering, University of West Bohemia. The turbine is placed in the suction of a compressor (see Fig. 1.). Inlet and outlet stage pressures and temperatures, turbine revolutions and torque are measured to calculate the stage power and efficiency. The rig is equipped with a traversing device which allows detail measurements of flow fields behind stator and rotor blades. A five-hole probe is used for the flow field measurement; losses of nozzle and bucket row can be evaluated separately. The stage efficiency obtained by five-hole probe measurement is in a very good agreement with the efficiency stated from torque. Relative error of the efficiency measurement was calculated as $0.67 \%$. Detailed information about measurement and evaluation process and error estimation is given in [5].
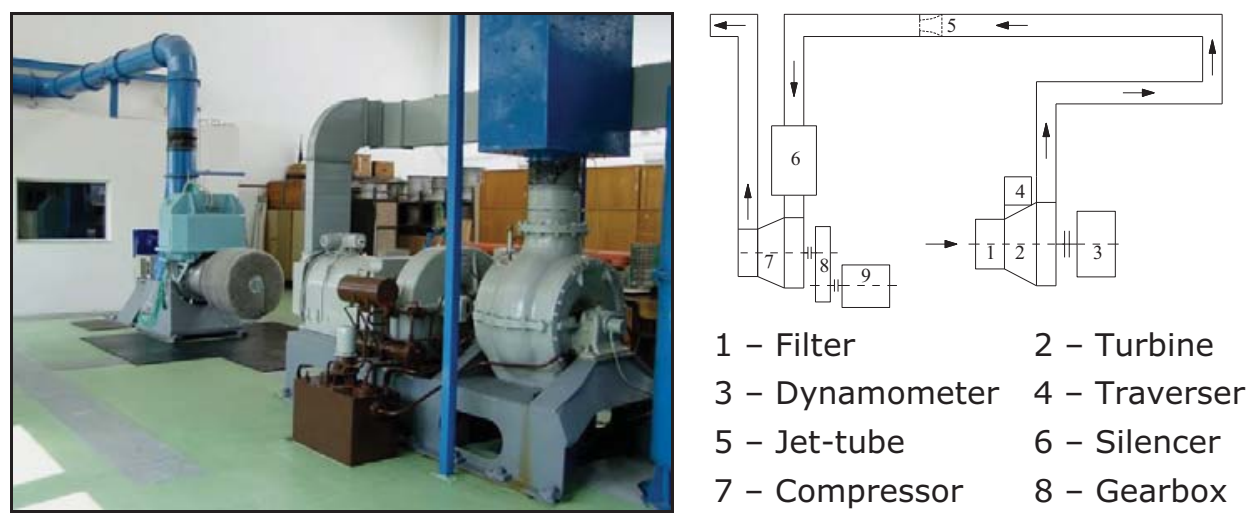

Figure 1: Experimental turbine

\section{TESTEd BLADINGS CASES}

The design of blades was done in a close cooperation with SKODA POWER and is based on the modern design of 3D bladings dedicated for HP and IP steam turbines. The basic geometrical data are in Tab. 1. The shape of nozzles (Fig. 2) uses the same 3D features. These are mainly the application of Compound Lean to weaken the secondary flow vortices resulting in reduction of endwall losses and Controlled Flow. This feature redistributes (control) the mass flow along the blade length, where the blade channel near endwalls is closed and the midspan region is opened. Practically it means that different cross section profiles are used in hub, midspan and tip.

\begin{tabular}{|c|c|c|}
\hline $\begin{array}{c}\text { nozzle }- \text { variant 1 } \\
\text { tested in } 2009\end{array}$ & $\begin{array}{c}\text { nozzle }- \text { variant 2 } \\
\text { tested in 2010 }\end{array}$ & $\begin{array}{c}\text { nozzle }- \text { variant 3 } \\
\text { will be tested in 2011 }\end{array}$ \\
\hline & & \\
\hline
\end{tabular}

Figure 2: Bladings 
The buckets were used the same for both tested nozzle cases as well as for the third case which is going to be tested. They are designed (Fig. 2, right) with increased reaction in the hub (moderate hub reaction stage). This means a slight close of the channel to increase the acceleration of the flow (and reaction as well) - the purpose is the additional loss reduction. The modification of the leading edge is the essential feature of the bucket 3D shaping. The shape is adjusted by cross profile turning and partial modification to adapt the outlet flow field from nozzles with controlled flow. Therefore this stage is designated as „Full3D”.

Table 1: Basic geometrical data

\begin{tabular}{|c|c|c|c|c|c|c|c|c|}
\hline & \multicolumn{4}{|c|}{ nozzles (stator blades) } & \multicolumn{4}{|c|}{ buckets (rotor blades) } \\
\hline & $\mathrm{D}_{\mathrm{h}}[\mathrm{mm}]$ & $L[\mathrm{~mm}]$ & $N$ [1] & $\mathrm{t} / \mathrm{B}_{\mathrm{ax}}[1]$ & $\mathrm{D}_{\mathrm{h}}[\mathrm{mm}]$ & $\mathrm{L}[\mathrm{mm}]$ & $\mathrm{N}[1]$ & $\mathrm{t} / \mathrm{B}_{\mathrm{ax}}[1]$ \\
\hline variant 1 & \multirow{3}{*}{400} & \multirow{3}{*}{44.5} & 42 & 0.61 & \multirow{3}{*}{400} & \multirow{3}{*}{47} & \multirow{3}{*}{56} & \multirow{3}{*}{0.75} \\
\hline variant 2 & & & 21 & 1.12 & & & & \\
\hline variant $3^{*}$ & & & 28 & 0.92 & & & & \\
\hline
\end{tabular}

going to be tested in 2011

\section{REsults}

The employed testing procedure was developed and successfully verified in previous experimental work (see references) hence was used without any changes. Experiments were done in revolution 2300 RPM. The efficiency (and other parameters) was firstly measured as a function of velocity ratio $u / c$. After that the flow field measurement behind stator and than behind rotor at the optimal working mode, i.e. operation with the highest efficiency, was done. Acquired data were also compared with data from stage of original prismatic design (prismatic both nozzles and also buckets blades).

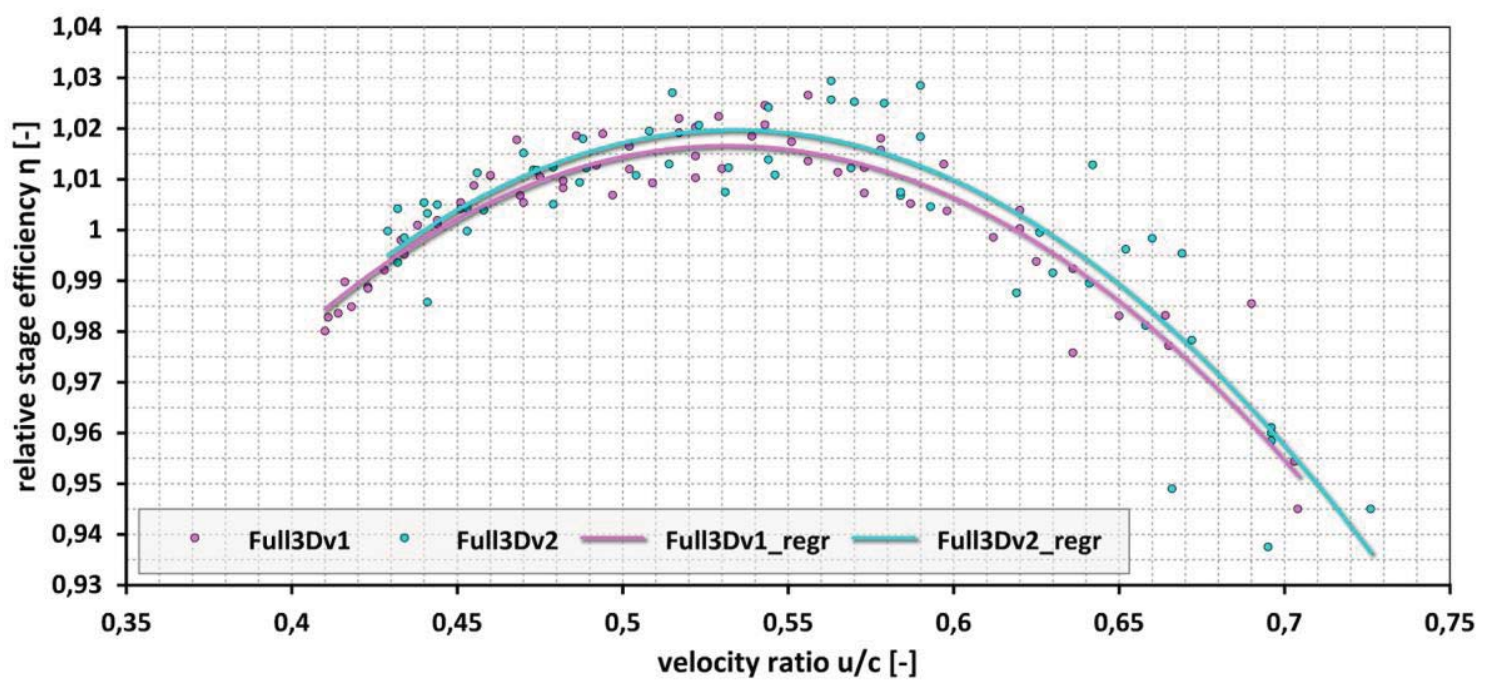

Figure 3: Relative stage efficiency in the dependency on velocity ratio $u / c$

\section{Stage efficiency}

The stage efficiency was measured at constant 2300 RPM and the velocity ratio $u / c$ has been adjusting by changing the stage pressure drop. That was set by the blower power 
to reach a range about 2500-7000 $\mathrm{Pa}$. For this pressure drop range we got the velocity ratio range of $u / c \sim 0.41-0.73$.

The results of this measurement are in Fig. 3. The efficiency here is shown as a ratio to the highest efficiency of the reference (Prismatic) bladings. Optimal velocity ratio for both investigated cases is approximately the same 0.53 (pressure drop about $4300 \mathrm{~Pa}$ ).

The comparison of the optimal operation mode data for Full3D bladings and original Prismatic bladings is in Tab. 2.

Table 2: Efficiency and optimal velocity ratio comparison

\begin{tabular}{|l|c|c|c|}
\hline bladings & Prismatic & Full3Dv1 & Full3Dv2 \\
\hline relative stage efficiency [1] & 1 & 1.0173 & 1.0185 \\
\hline optimal velocity ratio [1] & 0.49 & 0.53 & 0.53 \\
\hline
\end{tabular}

\section{Flow fields measurement}

Five-hole probe measurement was done at the optimal regime $(u / c=0.53)$ in the plane $11 \mathrm{~mm}$ downstream the nozzles trailing edges, respectively $10 \mathrm{~mm}$ behind the buckets trailing edges.

The spanwise stage reaction distribution is presented in Fig. 4. One can clearly see that the Full3D cases are designed with lower reaction than Prismatic case. Both new cases have also practically the same reaction distribution (only a small deviation in the hub region is present).

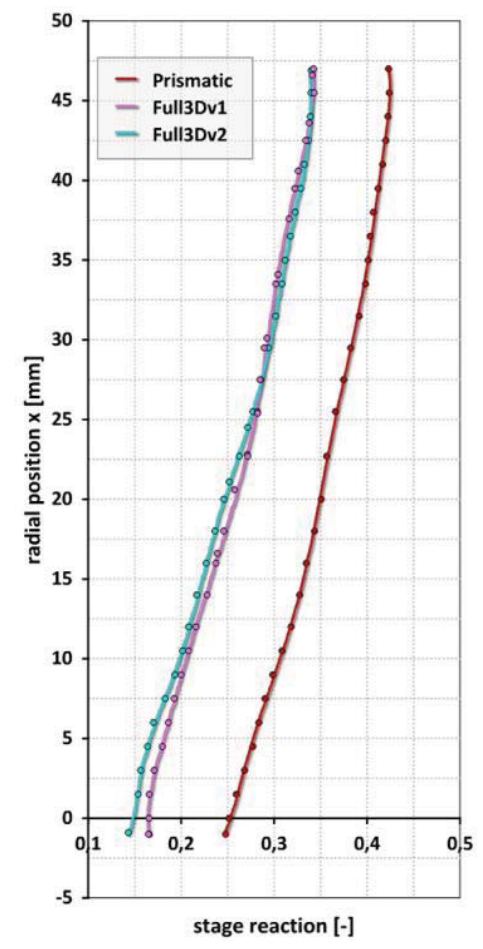

Figure 4: Stage reaction

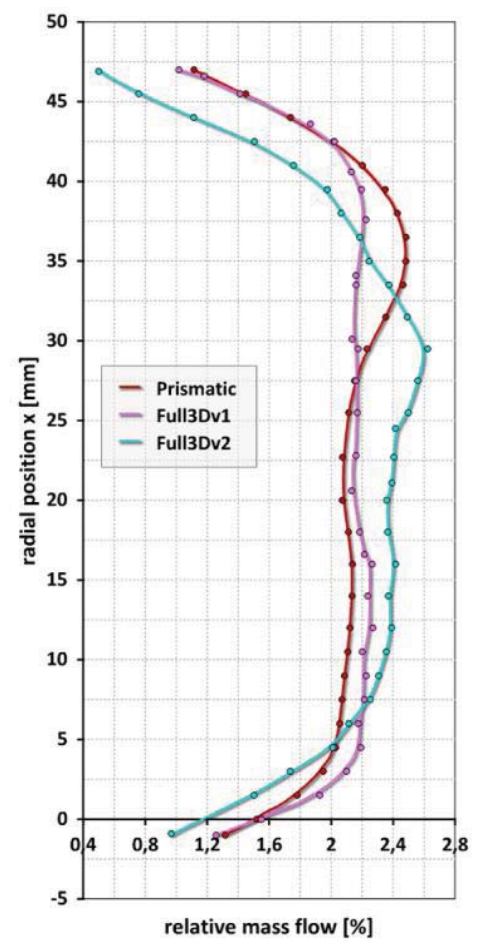

Figure 5: Relative mass flow

Fig. 5 shows the relative mass flow distribution. The effect of controlled flow in case of Full3D curves in comparison with Prismatic bladings is clearly visible - reduction of the flow near endwalls and increase in the midspan region. Full3Dv1 redistributes the flow quite equally between 5-40 mm of the span. The CF effect is in the case of Full3Dv2 even stronger - this is probably connected with lower row density. 
Mainly the losses, respectively the loss coefficient $\zeta$ Are the effectivity indicator of the bladings. One can see from the stage efficiency comparison above that there is just a very small difference between the $3 \mathrm{D}$ bladings cases. However, the conclusion is quite different when losses are observed separatelly in stator and in rotor. The Fig. 6. presents spanwise loss coefficient distribution in stator, rotor and whole stage got from five-hole probe measurement.
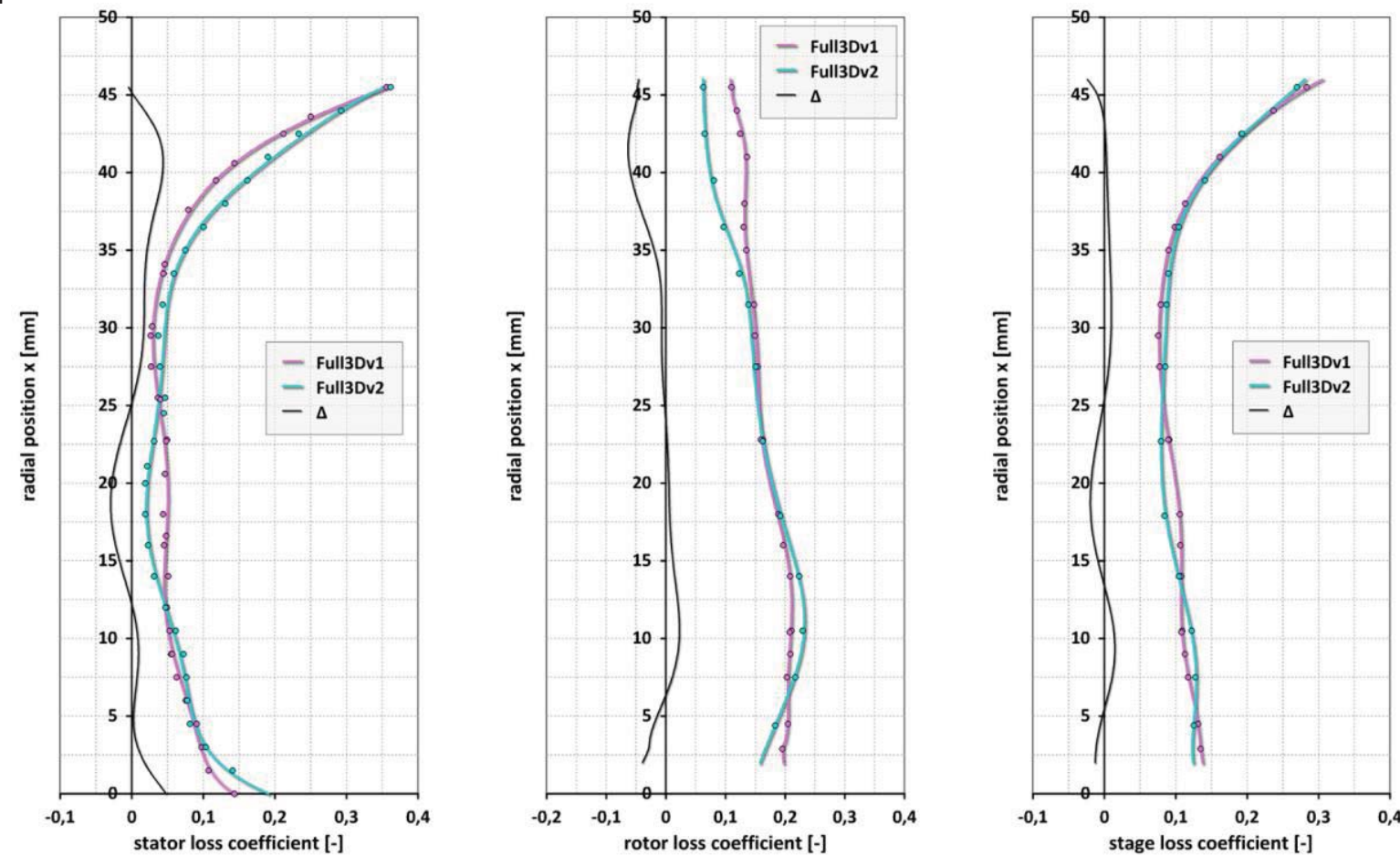

Figure 6: Comparison of losses between Full3Dv1 and Full3Dv2

For the case of stator blade row the losses of Full3Dv2 are slightly higher against Full3Dv1. The worsening is present primarily near endwalls and considerably near the tip endwall. The averaged value increases about $0.7 \%$ (absolute difference). The reason for this is probably the strong mass flow redistribution mentioned above. On the other hand, the rotor loss distribution in Fig. 6 (in the middle) clearly says that this strong flow reduction near the endwalls lowers the losses here remarkably. After averaging over the spanwise we get the rotor loss reduction about 1.2\% (absolute difference). Left chart in Fig. 6 shows losses of the whole stage. The differences here are very small, which is in an agreement with the results from stage efficiency measurement based on torgue.

A summary of these results is given in the Tab. 3. Efficiencies (supplement to 1) are shown here instead of losses for better comparison with data from torque measurement. All values are given as relative to the Prismatic bladings efficiency measured by torque.

Table 3: Comparison of relative efficiencies

\begin{tabular}{|c|c|c|c|c|c|c|}
\hline \multicolumn{2}{|c|}{ bladings } & & \multicolumn{2}{c|}{ five-hole probe measurement } & $\begin{array}{c}\text { torgue } \\
\text { measur. }\end{array}$ \\
\hline Nozzles & Buckets & & STATOR & ROTOR & STAGE & STAGE \\
\hline Prismatic & Prismatic & $\eta / \eta_{\text {ref }}[1]$ & 1.0580 & 0.9281 & 0.9972 & 1.0000 \\
\hline Full3Dv1 & $\eta / \eta_{\text {ref }}[1]$ & 1.0621 & 0.9619 & 1.0173 & 1.0173 \\
\hline \multicolumn{2}{|c|}{ Full3Dv2 } & $\eta / \eta_{\text {ref }}[1]$ & 1.0541 & 0.9762 & 1.0183 & 1.0185 \\
\hline
\end{tabular}




\section{Conclusions}

Paper presents new results of continuing research focused on the influence of 3D shaping of steam turbine blades. The attenttion is dedicated to the influence of nozzle row density. Two stage cases were tested - Full3Dv1 (high-density row) and Full3Dv2 (lowdensity row).

Only very small difference was found in the overall stage efficiency (Full3Dv2 was negligibly better). On the contrary, strong influence was observed on the mass flow redistribution despide the fact, that the bladings shaping was based on the same principle. This mass flow redistribution change in Full3Dv2 had negative effect on losses in nozzles, but contributed to the loss reduction downstream in bucket row.

The reduction of the number of nozzles (low-density row) also seems to contribute to a small reduction in profile loss (wake loss) - in the left chart in Fig. 6 a moderate loss reduction in the midspan region is present.

The decision about the use of low- or high-density row is managed by stress requirements together with the requirements on specific blade number ratio. In the design of HP and IP turbines the high-density row is used for couple of first stages. The low-density row is dedicated primariliy for end part of the flow path. Middle density row is usualy present in the central part. This type of bladings with relative axial width $t / B_{a x}=0.92$ is going to be tested in next experiments later in 2011.

\section{ACKNOWLEDGEMENT}

Research works have been supported by the research centre PTSE (1M06059) and by the student grant project "Zvyšování účinnosti, spolehlivosti a životnosti energetických strojů a zařízení" (SGS-2010-040).

\section{REFERENCES}

[1] MILCAK, P., HOZNEDL, M.: Measurement of Flow Fields on a Turbine Stage With 3D Blades. In Experimental Fluid Mechanics 2010, Liberec: Technical University of Liberec, p. 417-422, ISBN: 978-80-7372-670-6.

[2] MILČÁK, P., HOZNEDL, M., KRIVÁNKA, D. Testování turbínového stupně S 3D lopatkováním - úvodní experimenty. In Strojárstvo, Mechanical Engineering Journal, ISSN 1335-2938, 2009.

[3] MILCAK, P. Secondary Flows and Losses - Possibilities for Reduction and Some Experimental Results. In Acta Avionica, October 2008, ISSN 1335-9479.

[4] MILČÁK, P.; HOZNEDL, M. Results of the experimental testing of a stage with 3D shaped blades and design of a new stage. In Cieplne maszyny przeplywowe. Turbomachinery No. 133, Lodz : Technical University of Lodz, September 2008. s. 229-236. ISSN 0137-2661.

[5] MILČÁK, P. Experimentální výzkum vlivu prostorového tvarování lopatek na proudění a ztráty v turbínových stupních. dizertační práce, ZČU v PIzni, 2010. 